\title{
Methods of discard ewes carcass suspension and the quality of meat
}

\author{
Métodos de suspensão da carcaça de ovelhas de descarte na qualidade da carne
}

\author{
Rafael Silvio Bonilha PINHEIRO ${ }^{1 *}$, Hirasilva Borba Alves de SOUZA²
}

\begin{abstract}
The objective of this study was to evaluate the carcass suspension method concerning quality of sheep meat. Ten discard ewes were used, with approximately $62 \mathrm{~kg}$ of body weight. After slaughtering, flaying, evisceration and removal of head and paws, carcasses were longitudinally divided into two parts. Alternated sides of half carcasses were hanged by the tendon of the gastrocnemius (Treatment $1-\mathrm{T} 1)$ and by the pelvic bone (Treatment 2 - T2) in cold store for a 24-hour period. Subsequently, the Semimembranosus muscle was removed from all half carcasses for meat quality analyses. The Semimembranosus muscles from the carcasses hanged by the pelvis suspension method presented higher softness than the same muscles from the carcasses hanged by the tendon of the gastrocnemius, with values of $1.99 \mathrm{kgf.cm}^{-2}$ and $3.15 \mathrm{kgf.cm}{ }^{-2}$, respectively. Treatment 2 presented lower meat cooking losses than Treatment 1, with average values of 32.14 and $33.44 \%$, respectively. The remaining meat quality parameters evaluated were not influenced by the carcass suspension method. We concluded that the carcass suspension method influenced meat softness and losses by cooking, with better results for carcasses hanged by the pelvic bone.

Keywords: meat softness; sheep; tendon of the gastrocnemius.
\end{abstract}

\begin{abstract}
Resumo
Objetivou-se com este trabalho avaliar o método de pendura da carcaça quanto à qualidade da carne ovina. Foram utilizadas 10 ovelhas de descarte com aproximadamente $62 \mathrm{~kg}$ de peso corporal. Após abate, esfola, evisceração e retirada da cabeça e das patas, as carcaças foram divididas longitudinalmente em duas partes. Lados alternados das meias carcaças foram pendurados pelo tendão do gastrocnêmico, tratamento 1 (T1) e suspensos pelo osso pélvico (T2) por um período de 24 horas em câmara frigorífica. Posteriormente retirou-se o músculo Semimembranosus de todas as meias carcaças para as análises de qualidade da carne. Os músculos Semimembranosus das carcaças pendurados pelo método de suspensão da pelve apresentou maior maciez que os mesmos músculos das carcaças pendurados pelo tendão do gastrocnêmico, com valores de $1,99 \mathrm{kgf.cm} \mathrm{cm}^{-2}$ e $3,15 \mathrm{kgf.cm}{ }^{-2}$, respectivamente. O tratamento 2 obteve menores perdas por cocção da carne que o tratamento 1, com valores médios de 32,14 e 33,44\%, respectivamente. Os demais parâmetros de qualidade de carne avaliados não foram influenciados pelo método de suspensão da carcaça. Concluiu-se que o método de suspensão da carcaça, influenciou a maciez e as perdas por cocção da carne, sendo os melhores resultados para as carcaças penduras pelo osso pélvico.

Palavras-chave: maciez da carne; ovino; tendão do gastrocnêmico.
\end{abstract}

\section{Introduction}

Meat tenderness has been repeatedly reported by consumers as the most important aspect of quality, being determined by the amount and solubility of the conjunctive tissue, sarcomere shortening during the post mortem period and other factors (KOOHMARAIE; GEESINK, 2006). There is a negative correlation between meat tenderness and sarcomere length, being that shear force values decrease as sarcomere length increases (KOOHMARAIE, 1996).

According to Felício (2007a), the tenderness of almost all hind cuts may be improved by means of pelvic carcass hanging in the post mortem stage, mainly in meat proceeding from bovine breeds considered tougher. The method of suspension by the pelvic bone has been implemented in the United Kingdom and has been widely used in Ireland due to the demand for more tender meat provided by this hanging technique (TARRANT, 1998).

Carcass hanging by different methods during freezing in cold chamber influences tenderness grades in the sensorial analysis of some bovine carcass muscles (CIA; NORMAM, 1977). According to Felício (2007b), the carcass hanging method during freezing, when performed by the pelvis, decreases the need of meat maturation, since it provides higher tenderness in some carcass cuts. The disadvantage of this method in bovine carcasses is that the rear limb forms a $90^{\circ}$ angle and requires a larger space in the cold chamber (SORHEIM et al., 2001). However, it is unknown if this report may be considered for sheep carcasses, too, because they are much smaller and

Recebido para publicação em 11/5/2009

Aceito para publicação em 19/10/2009 (004194)

Departamento de Biologia e Zootecnia, Faculdade de Engenharia de Ilha Solteira - FEIS, Universidade Estadual Paulista "Júlio de Mesquita Filho" - UNESP,

Passeio Monção, 226, CEP 15385-000, Ilha Solteira - SP, Brasil, E-mail: rafaelsbp@bio.feis.unesp.br

2 Departamento de Tecnologia de Alimentos, Faculdade de Ciências Agrárias e Veterinárias - FCAV, Universidade Estadual Paulista "Júlio de Mesquita Filho" - UNESP,

Via de Acesso Prof. Paulo Donato Castellane, s/n, CEP 14884-900, Jaboticabal - SP, Brasil

${ }^{*}$ A quem a correspondência deve ser enviada 
lighter than the bovine ones and also because of lack of studies evaluating the carcass hanging method for this animal species.

Carcasses hanging by means of the pelvic bone, instead of the conventional process by the tendon of the gastrocnemius, allow bovine hindquarter meat to become more tender, except for the Psoas major muscle, which is kept distended. According to Pardi et al. (2001), the tension degree is a factor that partially influences the shortening caused by rigor mortis. Thus, muscles that present maximum tension during rigor mortis become tender, showing longer sarcomeres and, consequently, holding a reduced contraction condition after rigour and, thus, become more tender than the freely shortened ones.

Slaughtered old ewes usually present less tender meat, considered as low quality and, many times, undesired by lots of consumers. Therefore, techniques that provide improvement of meat tenderness, mainly meat from discard sheep, are valid, aiming to improve its quality, aggregate commercial value and, consequently, increase consumers' acceptance.

The objective of this work was to verify the carcass hanging method during a period of 24 hours in refrigerating chamber to evaluate meat quality (Semimembranosus muscle) proceeding from $1 / 2$ Ile de France $1 / 2$ Santa Inês discard ewes.

\section{Materials and methods}

Ten $1 / 2$ Ile de France $1 / 2$ Santa Inês discard ewes were used, with average body weight of $62 \mathrm{~kg}$ and approximately 50 months old. The animals were raised in pasture regime with African star grass (Cynodon nlemfuensis, Vanderyst) and supplemented daily with concentrate ( $0.5 \%$ of body weight), made up with crushed corn grain, soy bran, wheat bran, white salt and mineral and vitamin supplement.

Ewes were discarded because they were not pregnant after breeding season, diagnosed by means of ultrasound examination.

Before slaughtering, the animals were submitted to fasting of solid food for an average period of 16 hours. Next, ewes were left unconscious by means of electronarcosis and, afterwards, they had jugular veins and carotid arteries sectioned for bloodletting.

After flaying, evisceration and removal of head and paws, carcasses were longitudinally divided into two parts. Alternate sides of half-carcasses (right and left) were hanged by the conventional method (gastrocnemial tendon) (treatment 1 - T1) and also hanged by the pelvic bone (treatment $2-\mathrm{T} 2$ ). After that, they were transferred to a refrigerating chamber at $4{ }^{\circ} \mathrm{C}$ for 24 hours. At the end of this period, the Semimembranosus muscles (topside) were collected from all half-carcasses and packed in polyethylene bags, identified and frozen at $-18^{\circ} \mathrm{C}$ for later determinations of meat quality.

The $\mathrm{pH}$ was determined with a digital $\mathrm{pH}$ meter JONHIS brand, model IPHPJ by inserting the electrode directly into the Semimembranosus muscle. A Minolta chromarmeter, Model CR-300, set on the $L^{*}, a^{*}, b^{*}$ system (where $L^{*}$ measures relative lightness, $\mathrm{a}^{\star}$ relative redness and $\mathrm{b}^{*}$ relative yellowness) was used to measure meat color.

Water retention capacity of meat was calculated by using the methodology described by Hamm (1960), expressed by the loss of released water after pressing the muscle. Meat samples of $0.5 \mathrm{~g}$ were placed between two round filtering papers, between two acrylic plates, and then a $10 \mathrm{~kg}$ weight was placed on them for 5 minutes. After this process, the samples were weighed again and, according to the differences in weight, the amount of lost water was calculated. The result was expressed in percentage of water exuded in relation to sample weight.

A gas oven preheated at the temperature of $170^{\circ} \mathrm{C}$ was used to obtain losses by cooking. Raw meat samples were weighed and placed on trays with iron grills and weighed again. Next, samples were transferred to the oven, where they were kept until the internal temperature of sample core reached $75{ }^{\circ} \mathrm{C}$. After that, the trays with the grills and samples were taken away from the oven and, when cooled, weighed again for calculation of water loss percentage during cooking. The result was expressed in percentage.

For shear force, the same samples used to analyze water losses by cooking were employed; after being weighed, they were sliced in pieces of approximately $2 \times 2 \times 2 \mathrm{~cm}$ and submitted to transversal cut of muscle fibers, by means of a Warner-Bratzer blade attached to a Texture Analyzer equipment, with values expressed in kgf. $\mathrm{cm}^{-2}$.

The totally randomized design was used, with two treatments (hanging of half-carcass by the gastrocnemial tendon and by the pelvis) and ten repetitions, totalizing 20 experimental parcels. The analysis of variance and the $F$ test were carried out according to procedures of Statistical Analysis System (1996) software, considering the significance level of 5\%. The statistical model was (Equation 1):

$Y i j=\mu+T i+e i j$

where: Yij = value observed for the characteristic analyzed; $\mu=$ general average; $\mathrm{Ti}=$ effect of treatment $\mathrm{i}$; Eij $=$ experimental error.

\section{Results and discussion}

Averages and standard errors of $\mathrm{pH}$ and color $\left(\mathrm{L}^{*}, \mathrm{a}^{*} \mathrm{e} \mathrm{b}^{*}\right)$ values of the Semimembranosus muscle of carcasses of $1 / 2$ Ile de France $1 / 2$ Santa Inês ewes, hanged by different methods during the freezing period, are found in Table 1.

Meat $\mathrm{pH}$ was not influenced $(\mathrm{p}>0.05)$ by the sheep carcass hanging method, with average value of 5.62. Luchiari Filho et al. (2005), when evaluating the method of carcass hanging by the tendon of the gastrocnemius of the special rear limb and by the radial carpus of the forelimb of Nelore calves, did not observe any difference in the value of meat $\mathrm{pH}$ for the different methods of carcass hanging, what it is in agreement with the results obtained in this study (Table 1). Oliveira et al. (2004), when evaluating the quality of meat from Santa Inês lambs, found the same meat $\mathrm{pH}$ values obtained in this study. 
Table 1. Averages and standard errors of $\mathrm{pH}$ and color values $\left(\mathrm{L}^{*}, \mathrm{a}^{*}\right.$ and $\left.\mathrm{b}^{*}\right)$ of the Semimembranosus muscle from sheep carcasses, hanged by different methods during freezing period.

\begin{tabular}{|c|c|c|c|c|}
\hline Variable & $\mathrm{T} 1$ & $\mathrm{~T} 2$ & $F$ test & CV (\%) \\
\hline $\mathrm{pH}$ & $5.61 \pm 0.03$ & $5.63 \pm 0.02$ & $3.07^{\mathrm{NS}}$ & 0.42 \\
\hline $\mathrm{L}^{*}$ & $35.16 \pm 0.86$ & $34.42 \pm 0.54$ & $0.53^{\mathrm{NS}}$ & 5.06 \\
\hline$a^{*}$ & $19.32 \pm 0.51$ & $19.71 \pm 0.30$ & $0.44^{\mathrm{NS}}$ & 5.29 \\
\hline
\end{tabular}

$\mathrm{T} 1=$ Half-carcasses hanged by the gastrocnemial tendon. $\mathrm{T} 2=$ Half-carcasses hanged by the pelvic bone. $\mathrm{CV}=$ variation coefficient. NS $=$ Not significant $(\mathrm{p}>0.05)$.

The color of the Semimembranosus muscle of the carcass of discard ewes, hanged by the gastrocnemial tendon and by the pelvic bone, presented similar values $(p>0.05)$ for $L^{*}, a^{*}$ and $b^{*}$ contents, with averages of $34.79,19.51$ and 1.51 , respectively. Pinheiro (2006), when evaluating the color of meat from $1 / 2$ Ile de France $1 / 2$ Ideal discard ewes, whose carcasses were hanged by the gastrocnemial tendon, obtained values of 35.74, 19.18 and 1.65 for $L^{*}, a^{*}$ and $b^{*}$, respectively, for the same muscle used in this study. The values obtained by the author mentioned above are similar to the ones obtained in this research (Table 1).

The $\mathrm{pH}$ and color of meat are the most influenced factors by sheep pre- and post-slaughter management, especially in situations that cause animal stress before and during slaughter, unconsciousness method used and animal-related issues, such as age, sexual condition and breed, besides sheep production and nutrition systems. The method of carcass hanging did not influence quality parameters in the Semimembranosus muscle ( $\mathrm{pH}$ and color) during the period of 24 hours in refrigerating chamber, as observed in Table 1.

The results for tenderness, water retention capacity and losses by cooking obtained in this study concerning the Semimembranosus muscle from sheep carcasses, hanged by different methods for a cooling period of 24 hours, are found in Table 2.

The method of carcass hanging by the pelvis provided higher tenderness $(\mathrm{p}<0.01)$ of the Semimembranosus muscle $\left(1.99 \mathrm{kgf}_{\mathrm{cm}} \mathrm{cm}^{-2}\right.$ ), compared to the traditional method by the gastrocnemial tendon $\left(3.15 \mathrm{kgf} . \mathrm{cm}^{-2}\right)$. Similar results were obtained by Hostetler et al. (1972), when studying the effect of bovine carcass hanging as for shear force of meat, and also by Ahnström et al. (2003), when evaluating the effect of carcass hanging by the pelvis as for sensorial and instrumental evaluation of different bovine muscles.

According to Pardi et al. (2001), the tension degree partially influences the shortening caused by rigor mortis. Thus, muscles that present the maximum tension during rigour become more tender, showing longer sarcomeres and, consequently, remaining in reduced contraction after rigor and, thus, become more tender than the freely shortened ones.

Luchiari Filho et al. (2005), when evaluating carcasses from calves hanged by different methods, verified lower shear force in the Longissimus dorsi muscle for the method of hanging by the radial carpus $(3.53 \mathrm{~kg})$ than by the tendon of the gastrocnemius $(4.78 \mathrm{~kg})$ and no differences were obtained for the Biceps femoris muscle in the different hanging methods. According to these results, we can observe that not all muscles of the carcass are influenced by the hanging method, being, therefore, necessary to know all the muscles that may be modified as for tenderness and other meat quality parameters in each kind of carcass hanging, be it by tendon of the gastrocnemius, pelvic bone, radial carpus, horizontal disposal or other anatomic part of the animal carcass.

Ahnström et al. (2006), when studying the method of bovine carcass hanging, found that hanging by the pelvis considerably interfered in the shape and length of the Semimembranosus muscle, which was increased in relation to the same muscle whose carcass was hanged by the tendon of the gastrocnemius. Therefore, authors concluded that hanging by the pelvis may be a viable method to reduce variability in the texture of the Semimembranosus muscle of young bovines.

The water retention capacity of the meat was not different ( $p>0.05$ ) between hanging methods of the carcass from discard ewes, with average values of 53.13\%. Pinheiro (2006) obtained percentages near to the ones obtained in this work (Table 2) for water retention capacity $(54.46 \%)$ in the Semimembranosus muscle from discard ewes whose carcasses were hanged by the gastrocnemial tendon.

Values for losses by cooking of the Semimembranosus muscle were influenced $(\mathrm{p}<0.01)$ by the type of carcass hanging, in which carcasses hanged by the pelvic bone present lower percentages of losses by cooking in meat (32.44\%) compared to the traditional method of carcass hanging (gastrocnemial tendon), which obtained a higher value for the same muscle studied (33.44\%). According to Ahnström et al. (2006), the lowest losses during cooking preparation occurred for bovine meat whose carcass was hanged by the pelvis, agreeing with the occurrences in this study (Table 2). The increase of losses during meat cooking further than expected is undesirable, because of a decrease in yield, besides influencing organoleptic issues of meat quality.

Luchiari Filho et al. (2005), when evaluating bovine carcasses hanged by different methods, did not verify statistical differences among hanging methods for the percentages of meat total losses in cooking. Silva (2005) also did not find differences for values of losses by cooking of bovine meat proceeding from different methods of carcass hanging (tendon of the gastrocnemius, horizontal and radial carpus). These results do not agree with the ones obtained in this study (Table 2), probably due to the different methods of carcass hanging, muscles analyzed, methodology used in the analysis for determination of meat losses by cooking or even the animal species used. 
Table 2. Averages and standard error of softness, water retention capacity and losses by cooking values of the Semimembranosus muscle from carcasses from discard ewes, hanged by different methods during freezing period.

\begin{tabular}{ccccc}
\hline Variable & \multicolumn{1}{c}{ T1 } & T2 & \multicolumn{1}{c}{$F$ test } & CV (\%) \\
\hline Softness $\left(\mathrm{kgf.cm}^{-2}\right)$ & $3.15 \mathrm{a} \pm 0.10$ & $1.99 \mathrm{~b} \pm 0.09$ & $15.08^{* *}$ & 8.16 \\
CRA (\%) & $52.30 \pm 1.63$ & $53.97 \pm 1.27$ & $0.65^{\mathrm{NS}}$ & 6.76 \\
Losses by cooking (\%) & $33.44 \mathrm{a} \pm 0.44$ & $32.14 \mathrm{~b} \pm 0.37$ & $4.99^{* *}$ & 5.06 \\
\hline
\end{tabular}

$\mathrm{T} 1=$ Half-carcasses hanged by the gastrocnemial tendon. $\mathrm{T} 2=$ Half-carcasses hanged by the pelvic bone. $\mathrm{CRA}=$ water retention capacity. $\mathrm{CV}=$ variation coefficient. $\mathrm{NS}=$ not significant $(\mathrm{p}>0.05){ }^{* *}=$ significant $(\mathrm{p}<0.01)$.

\section{Conclusions}

The method of sheep carcass hanging during freezing period in refrigerating chamber for 24 hours influenced meat softness, being the pelvic hanging the most recommended method because it provided higher softness of the Semimenbranosus muscle from $1 \frac{1}{2}$ Ile de France $1 / 2$ Santa Ines discard ewes.

The method of carcass hanging did not interfere in meat quality parameters, such as $\mathrm{pH}$, color and water retention capacity.

Carcasses hanged by the gastrocnemial tendon presented higher losses by meat cooking than the ones hanged by the pelvic bone. Higher losses during meat preparation are undesirable to industries as well as to consumers, since they mean meat quantitative and qualitative losses.

\section{References}

AHNSTRÖM, M. L. et al. Effect of pelvic suspension on sensory and instrumental evaluation on four beef muscles in heifers and young bulls. In: $49^{\text {th }}$ International Congress of Meat Science and Technology, 49, 2003, Campinas. Proceedings...Campinas, 2003. p.161-162.

AHNSTRÖM, M. L. et al. Pelvic suspension improves quality characteristics in M. Semimembranosus from Swedish dual purpose young bulls. Meat Science, v. 72, n. 3, p. 555-559, 2006.

CIA, G.; NORMAN, G.A. Influência da pendura da carcaça imediatamente após o abate na maciez da carne bovina. Coletânea do ITAL, v. 8, p. 1-18, 1977.

FELÍCIO, P. E. Qualidade da carne nelore e o mercado mundial. Disponível em: <http://www.fea.unicamp.br/deptos/dta/carnes/ files/CarneNeloreMercadoMundial.pdf>. Acesso em: 23 jul. 2007a.

FELÍCIO, P. E. Classificação e tipificação de carcaças bovinas. Disponível em: <http://www.fea.unicamp.br/deptos/dta/carnes/ files/CTC_ITAL_06/Classificacao_e_Tipificacao.pdf $>$. Acesso em: 30 jul. $2007 b$.
HAMM, R. Biochemistry of meat hydration. Advances in Food Research, v. 10, p. 355-463, 1960.

HOSTETLER, R. L. et al. Effect of carcass suspension on sarcomere length and shear force of some major bovine muscles. Journal of Food Science, v. 37, n. 1, p.132-135, 1972.

KOOHMARAIE, M. Biochemical factors regulating the toughening and tenderization processes of meat. Meat Science, v. 43, p. 193-201, 1996.

KOOHMARAIE, M.; GEESINK, G. H. Contribution of postmortem muscle biochemistry to the delivery of consistent meat quality with particular focus on the calpain system. Meat Science, v. 74, n. 1, p. 34-43, 2006.

LUCHIARI FILHO, A. et al. Hanging the beef carcass by the forequarter to improve tenderness of the Longissimus dorsi and Biceps femoris muscles. Scientia Agricola, v. 62, n. 5, p. 483-486, 2005.

OLIVEIRA, I. et al. Caracterização do processo de rigor mortis em músculos de cordeiros e carneiros da raça Santa Inês e maciez da carne. Revista Acta Scientiae Veterinariae, v. 32, n. 1, p. 25-31, 2004.

PARDI, M. C. et al. Ciência, higiene e tecnologia da carne. 2. ed. Goiânia: UFG, 2001. v. 1, p.475-485.

PINHEIRO, R. S. B. Aspectos quantitativos da carcaça e qualitativos da carne de ovinos de diferentes categorias. 2006. $105 \mathrm{f}$ Dissertação (Mestrado em Zootecnia)-Faculdade de Ciências Agrárias e Veterinárias, Universidade Estadual Paulista, Jaboticabal, 2006.

STATISTICAL ANALISYS SYSTEM INSTITUTE. User's Guide to Statistics: Version 6.12. Cary: North Caroline State University, 1996.

SILVA, E. B. Proteólise miofibrilar e maciez da carne de bovinos (Bos indicus) submetidos a diferentes técnicas pós-morte de suspensão das carcaças. 2005. 49 f. Dissertação (Mestrado em Zootecnia)-Faculdade de Zootecnia e Engenharia de Alimentos, Universidade de São Paulo, Pirassununga, 2005.

SORHEIM, O. et al. Influence of beef carcass streching and chilling rate on tenderness of m. Longissimus dorsi. Meat Science, v. 57, n. 1, p. 79-85, 2001.

TARRANT, P.V. Some recent advances and future priorities in research for the meat industry. Meat Science, v. 49, n. 1, p. 1-16, 1998. 